\title{
ĐẶC ĐIỂM BỆNH NHÂN CHẤN THƯƠNG CộT SỐNG CỔ CAO TẠI BỆNH VIỆN TWQĐ 108
}

\author{
Trần Huy Hùng ${ }^{1}$, Ngô Chí Công ${ }^{1}$, Đinh Gia Khánh ${ }^{1}$
}

\section{TÓM TẮT}

Đặt vấn đề: Chấn thương cột sống cổ là chấn thương thường gặp, có thể để lại hậu quả nặng nề. Cột sống cổ cao có độ linh hoạt và ảnh hưởng rất lớn đển nhiêu chức năng sống. Tuy nhiên, các đăc điểm của chấn thương cột sống cố cao còn nghèo nàn, chẩn đoán khó khăn, dễ bỏ sót tổn thương. Đối tượng và phương pháp; Thiết kế nghiên cứu theo phương pháp mô tả cắt ngang, hồi cứu kết hợp tiến cứu trên 33 bệnh nhân được chẩn đoán chấn thương cột sống cổ cao tại Khoa cấp cứu - Bệnh viện TWQĐ 108 trong thời gian từ 04/2018 - 04/2021. Kết quả: Nguyên nhân chủ yếu là tai nạn giao thông $(63.6 \%)$ và chủ yếu găp ở nam giới $(84.8 \%)$, đa số trong lứa tuổi lao động (34.2 \pm 15.3). Tất cá các bệnh nhân đều có đau cổ, hạn chế vận động chiếm đa số (87.8\%). Các triệu chứng thực thể hay gặp là rối loạn cảm giác $(39.3 \%)$, liêt vân động (36.3\%). VAS trung bình là $5.54 \pm 1.6$. Tỷ lệ hình thái tổn thương hay gặp nhất là gãy C2 (66.67\%). Kết luâ̂n; Chấn thương cột sống cổ cao chủ yếu gặp ở nam giới, trong lứa tuổi lao đông, nguyên nhân chủ yếu do tai nạn giao thông. Đặc điểm lâm sàng chính là đau và hạn chế vận động vừng cổ, rối loạn cảm giác. Tổn thương thường gặp nhất là gãy C2.Keyword: Chấn thương cột sống cổ, cột sống cổ cao.

\section{SUMMARY \\ CHARACTERISTIC OF UPPER CERVICAL TRAUMA PATIENTS IN 108 HOSPITAL}

Background: Cervical spinal trauma is frequently trauma, has severe consequent. Upper cervical is flexible and has many effect to some lives-function. However, characteristics of upper cervical trauma are miserable, difficult diagnose and easy to lost injuries. Subject and methods: Studied design by crosssectional descriptive, retrospective and prospective of 33 patients had diagnosed upper cervical trauma in Emergency Department - 108 Hospital, from April 2018 to April 2021. Results: Main cause is traffic accident $(63.6 \%)$, male and labor-age is majority $84.8 \%$ and $34.2 \pm 15.3$, respectively. All patients has neck pain $(100 \%)$, neck difficult motion is majority $(87.8 \%)$. The most physical symptom of patients is dysesthesia, motion paralysis with percentage are $39.3 \%$ and $36.3 \%$, respectively. Average VAS is 5.54 \pm 1.6 . The most type of injuries is C2 fractures $(66.67 \%)$. Conclusion: Upper cervical trauma is majority in male, labor-age and main cause is traffic

${ }^{1}$ Bệnh viện TUQQĐ 108.

Chịu trách nhiệm chính: Trần Huy Hùng

Email: hungth.ss108@gmail.com

Ngày nhận bài; 13/5/2021

Ngày phản biên khoa học 7/6/2021

Ngày duyệt bài: 21/6/2021 accident. The main clinical characteristics is neck pain, neck difficult motion and dysesthesia. The most type of injuries is C2 fractures.

Keyword: Cervical trauma, upper cervical.

\section{I. ĐẶT VẤN ĐỀ}

Cột sống cổ là điểm tiếp nối giữa đâu và cơ thể người, vừa mềm dẻo, vừa vững chắc và bảo vệ tủy sống ở bên trong. Cột sônng cổ cao bao gồm C0 (lồi câu chẩm), C1 (đốt đội), C2 (đốt trục) và hệ thống dây chằng. Chấn thương cột sống cổ cao là những chấn thương vùng C0-C2 hay còn gọi là vùng bản lề cổ chẩm [1].

Chấn thương cột sống cổ là chấn thương thường gặp, chiếm khoảng $6 \%$ trong tất cảnhững trường hợp đa chấn thương, $40 \%$ trường hợp có tổn thương thân kinh, có thể để lai hậu quả năng nề như tổn thương thân kinh không hổi phục, thậm chí tử vong. Theo thống kê ở Mỹ hàng năm có hơn 11000 người bị chấn thương cột sống, tử vong trước khi vào viện là 4800 người. Tân suất gặp chấn thương cột sônng ở Mỹ là 53.4 người/1 triệu dân, ở pháp là 20 người/ 1 triệu dân. Nguyên nhân do tai nạn giao thông, tai nạn lao động và hay gặp ở các nước đang phát triển [2]. Cột sống cổ cao rất linh hoạt về mặt chức năng, được liên hệ với nhau bởi hệ thống dây chằng và diện khớp phức tạp do vậy các hình thái tổn thương cũng đa dạng và phức tạp [3].Triệu chứng lâm sàng chấn thương cột sống cỗ cao thường nghèo nàn, dễ bỏ sót và nhầm lẫn với triệu chứng cột sống cổ thấp làm chậm các chỉ định điều trị, dẫn đến những di chứng nặng nề về sau cho bệnh nhân. Tỷ lệ bỏ sót tổn thương cột sống cổ cao là $60-70 \%$, một con số đáng báo động [1].

Vì vậy, với những đặc điểm trên, chúng tôi tiến hành nghiên cứu đề tài này đánh giá và mô tả lại những đặc điểm của bệnh nhân chấn thướng cột sống cổ cao.

\section{II. ĐỐl TƯỢNG VÀ PHƯƠNG PHÁP NGHIÊN CỨU}

2.1. Đối tượng nghiên cứu: Gồm 33 bệnh nhân được chẩn đoán chấn thương cột sống cổ cao tại Khoa cấp cứu - Bệnh viện TWQĐ 108, trong thời gian từ 04/2018 tới 04/2021.

\subsection{Phương pháp nghiên cứu:}

- Thiết kế nghiên cứu Mô tả cắt ngang, hồi cứu kết hợp tiến cứu

- Xử lý số liệu: Bằng phân mềm thống kê y hoc SPSS 20.0 
III. KẾT QUẢ NGHIÊN CỨU VÀ BÀN LUẬN

\section{1.Đặc điểm chung}

Bảng 1. Đặc điểm chung của bệnh nhân chân thương cột sông cổ cao

\begin{tabular}{|c|c|c|}
\hline Nguyên nhân & $\begin{array}{c}\text { Số lượng } \\
\text { (n) }\end{array}$ & $\begin{array}{c}\text { Tỷ lệe } \\
(\mathbf{\%})\end{array}$ \\
\hline Tai nạn giao thông & 21 & 63.6 \\
\hline Tai nạn lao động & 10 & 30.3 \\
\hline Nguyên nhân khác & 2 & 6.1 \\
\hline Giới tính & Số lượng & Tỳ lệ \\
\hline Nam & 28 & 84.8 \\
\hline Nữ & 5 & 15.2 \\
\hline \multicolumn{2}{|c|}{ Tuối trung bình: 34.2 15.3} \\
\hline
\end{tabular}

Trong 33 bệnh nhân nghiên cứu, nhỏ tuổi nhất là 16 tuổi, cao tuổi nhất là 62 tuổi, độ tuổi trung bình là $34.2 \pm 15.3$; là độ tuổi lao động chính trong xã hội. Có 28 bệnh nhân nam, 5 bệnh nhân nữ. Nguyên nhân chủ yếu là tai nạn giao thông (21 trường hợp), chiếm 63.6\%. Kết quả trên là tương đương với nhiều nhóm tác giả khác [2]. Nhìn chung tỷ lệ chấn thương cột sống cổ ở nam cao hơn nữ là do đặc thù nam giới lao động trong những ngành nghề nhiều rủi ro hơn, nặng nhoc hơn; còn khi tham gia giao thông thì nam giới có xu hướng kém cẩn thận và mạo hiểm hơn nữ giới. Điều này là khác biệt so với nghiên cứu ở các nước phát triển, nguyên nhân do tai nạn giao thông là khá thấp [2], cho thấy ý thức tham gia giao thông và nền tảng cơ sở hạ tầng ở nước ta còn thấp. Qua đó, cũng góp phần đưa ra các lưu ý cho các bác sĩ lâm sàng khi thăm khám và chẩn đoán chấn thương cột sống tránh bỏ sót tổn thương này.

3.2. Đặc điểm lâm sang. Tất cả bệnh nhân đều có đau cổ, 33 bệnh nhân (100\%), kèm theo triệu chứng hạn chế vận động cổ là 29/33 $(87.8 \%)$, co cứng cổ là 22/33 (66.7\%). Các triệu chứng thực thể hay gặp nhất là rối loạn cảm giác, 13 trường hợp (39.3\%); liệt vận động là 12 trường hợp (36.3\%), rối loạn cơ tròn là 5 trường hợp $(15.1 \%)$, tổn thương phối hợp là 8 trường hợp (24.2\%). Điểm VAS trung bình là $5.54 \pm 1.6$, cao nhất là 7 điểm, thấp nhất là 2 điểm (Bảng 2).

Kết quả trên là cũng khá tương đồng với nhiều nghiên cứu của các tác giả khác [2], [3],[4],[5]. Qua nghiên cứu chúng tôi thấy triêu chứng đau cổ và hạn chế vận động cổ là chủ yếu. Mặc dù điểm VAS trung bình không quá cao, cho thấy chấn thương cột sống cổ cao không quá đau. Tuy nhiên, qua đó chúng tôi khuyến cáo khi thăm khám bệnh nhân sau chấn thương có biểu hiện đau hoặc hạn chễ vận động cột sống cổ, dù không quá dữ dội cần khám kỹ càng tránh bỏ sót chấn thương cột sống cổ cao.
Tỷ lệ rối loạn cảm giác nhiều nhưng không phải là dấu hiệu quan trọng vì triệu chứng này dễ nhầm lẫn với các tổn thương không phải do chấn thương cột sống cổ, phụ thuộc vào cảm giác chủ quan của người bệnh.

Bảng 2. Đặc điểm lâm sàng bệnh nhân chấn thương côt sống cố

\begin{tabular}{|c|c|c|}
\hline & Số lượng (n) & Tỷ lệ (\%) \\
\hline \multicolumn{2}{|c|}{ Triệu chứng cơ năng } \\
\hline Đau cố & 33 & 100 \\
\hline Co cứng cố & 22 & 66.67 \\
\hline $\begin{array}{c}\text { Hạn chế vận } \\
\text { động cổ }\end{array}$ & 29 & 87.8 \\
\hline \multicolumn{2}{|c|}{ VAS trung bình: $5.54 \pm 1.6$} \\
\hline \multicolumn{2}{|c|}{ Triệu chứng thực thế } \\
\hline Rối loạn cảm giác & 13 & 39.3 \\
\hline Rối loạn cơ tròn & 5 & 15.1 \\
\hline Liệt vận động & 12 & 36.3 \\
\hline $\begin{array}{c}\text { Tốn thương phối } \\
\text { hợp }\end{array}$ & 8 & 24.2 \\
\hline
\end{tabular}

\section{3. Đặc điếm cận lâm sàng}

Bảng 3. Đặc điểm cận lâm sàng

\begin{tabular}{|c|c|c|}
\hline $\begin{array}{c}\text { Hình thái tốn } \\
\text { thương }\end{array}$ & $\begin{array}{c}\text { Số lươong } \\
\text { (n) }\end{array}$ & $\begin{array}{c}\text { Tỷ lề } \\
\text { (\%) }\end{array}$ \\
\hline Gãy C1 & 3 & 9.09 \\
\hline Gãy C2 & 22 & 66.66 \\
\hline Trật C1-C2 & 8 & 24.24 \\
\hline
\end{tabular}

Trong nghiên cứu của chúng tôi, tỳ lệ gãy $\mathrm{C} 2$ là cao nhất, 22 trường hợp $(66.66 \%)$. Sau đó là đến gãy $\mathrm{C} 1$ (3 trường hợp), trật C1-C2 (8 trường hợp), không có trường hợp nào gãy $\mathrm{C} 0$. Kết quả này là tương đồng với Vũ Văn Cường [5], Nguyễn Trọng Hiếu [2]. Tác giả Nguyễn Viết Lực và CS [3], có kết quả tỷ lệ gãy trật $\mathrm{C} 1-\mathrm{C} 2$ là nhiêu nhất $(61.3 \%)$, và theo như nhóm tác giả giải thích có thể do nhóm đối tượng bệnh nhân trong nghiên cứu là nhóm bệnh nhân có chỉ định nẹp cổ chẩm, không có phương án khác.

Tất cả những bệnh nhân trong nghiên cứu của chúng tôi đều được chụp phim X-Quang và CLVT (cắt lớp vi tính) cột sống cổ. Dựa trên kết quả hình ảnh, chúng tôi thấy rằng phim $X-Q u a n g$ quy ước rẻ tiền, có thể thực hiện được hầu như ở tất cả các tuyến nhưng độ chính xác khá thấp, dễ bỏ sót nhiều tổn thương so với phim CLVT. Do đó những chấn thương cột sống cổ, chúng tôi khuyến cáo ngoài việc khám xét kỹ các triệu chứng lâm sàng thì nên chỉ định chụp CLVT cột sống cổ để tránh bỏ sót và đánh giá chính xác tổn thương cột sống cổ.

\section{KẾT LUẬN}

Chấn thương cột sống cổ cao chủ yếu gặp ở nam giới $(84.8 \%)$, trong lứa tuổi lao động (34.2 \pm 15.3$)$ và nguyên nhân chủ yếu do tai nạn 
giao thông (63.6\%). Đăc điểm lâm sàng chính là đau $(100 \%)$ và hạn chế vận động cổ $(87.8 \%)$, rối loạn cảm giác(39.3\%). Tổn thương thường gặp nhất là gãy C2 (66.7\%), không có trường hợp nào gãy lồi cầu chẩm $(\mathrm{C} 0)$.

\section{TÀI LIÊU THAM KHẢO}

1. Herkowitz, H.N., et al., Rothman-Simeone The Spine E-Book: Expert Consult. Vol. 1. 2011: Elsevier Health Sciences.

2. Nguyển Trọng Hiếu và cs, Đă̆c điểm lâm sàng và cận lâm sàng chấn thương cột sống cổ $\mathrm{C} 1-\mathrm{C} 2$,
Tạp chí Y học thực hành, số 9/2011, tr.77 - 79.

3. Nguyễn Viết Lực, Nguyển Lê Bảo Tiến, và CS., Đặc điểm lâm sàng và cận lâm sàng của bệnh nhân chấn thương cột sống cổ cao, Tạp chí Y học Viêt Nam, số 2 - 2021, tr $207-209$.

4. Hà Kim Trung, Nghiên cứu chẩn đoán và phẫu thuât chấn thương côt sống cố có tổn thương thần kinh tại Bệnh viện Việt Đức, Luận án Tiến sĩ y học, Đai hoc Y Hà Nổi, 2005.

5. Vũ̃ Văn Cường, Nghiên cứu ứng dụng kỹ thuât harms cải tiến trong điêu trị chân thương mất vững C1-C2. Luận án Tiến sĩ Y học, Đại học Y Hà Nội, 2018.

\section{ĐÁNH GIÁ HOẠT TÍNH CHỈNH SỬA GEN BCL11A TRÊN THỰC NGHIÊMM CỦA PROTEIN CAS9 TÁI TỔ HỢP, ĐỊNH HƯỚNG ỨNG DỤNG ĐIỀU TRI BỆNH HỒNG CẦU LIỀM}

\section{TÓM TẮT}

Mục tiêu: Thiết kế phức hợp rCas9/sgRNA để chỉnh sửa gen $B C L 11 A$ tách dòng vào plasmid pJET1.2 trong điêu kiên in vitro nhằm đánh giá hoạt tính protein Cas9 tái tổ hợp và định hướng ứng dụng điều tri bênh hồng câu liềm. Đối tượng và phương pháp: Khuếch đại vùng Enhancer của gen $B C L 11 A$ bằng phản ứng $P C R$, phân tích so sánh trình tự với DNA của người Việt Nam. Thiết kế chuỗi đơn RNA dẫn đường (sgRNA) và tao phức hợp rCas9/sgRNA. Thử nghiệm hoạt tính phức hợp trêngen BCL11A đã được tách dòng vào plasmid pJET1.2 trong điều kiên in vitro. Kết quả: Phức hợp rCas9/sgRNA tổng hợp được đã cắt vùng enhancer của gen BCL11Atrên in vitro thành 2 sản phẩm có kích thước khoảng 240bp. Giải trình tự gen sảm phẩm $\mathrm{PCR}$ cho thẩy phức hợp rCas9/sgRNA đã cắt vùng gen enhancer GATAA của BCL11A tại vị trí cách vùng PAM 3 cặp nucleotide theo đúng tính toán lý thuyết. Kết luận: Protein Cas9 tái tổ hợp có hoạt tính tương tự protein Cas9 tự nhiên và phức hợp rCas9/sgRNAcần được tiếp tục nghiên cứu đêứng dụng trong chỉnh sửa gen $B C L 11 A$ điều trị bệnh hồng câu liềm trên lâm sàng.

Tư khóa: Hệ thống CRISPR/Cas9, bệnh hồng cầu liềm, chỉnh sửa gen

\section{SUMMARY}

EVALUATION OF RECOMBINANT CAS9

PROTEIN IN-VITRO EDITING OF BCL11A GENE FOR CURING SICKLE CELL DISEASE

Objective: To design a rCas9/sgRNA complex for editting of BCL11A gene in in-vitro and evaluation of

*Bệnh viện Quân y 103

Chịu trách nhiệm chính: Đỗ Như Bình

Email: nhubinh.do@vmmu.edu.vn

Ngày nhận bài: 25/4/2021

Ngày phản biên khoa hoc: 25/5/2021

Ngày duyệt bài: 17/6/2021
Đỗ Như Bình*

recombinant Cas9 protein activity for orientational applying in the treatment of sickle cell disease. Materials and methods: Amplification of the enhancer region of the BCL11A gene by PCR, sequencingand comparing with Vietnamese DNA. Design a single-strand guide RNA (sgRNA) and create an rCas9/sgRNA complex. Evaluate the activity rCas9/sgRNA complex on the BCL11A gene cloned into the pJET1.2 plasmid under in vitro condition. Results: The synthesized rCas9/sgRNA complex has cleaved the enhancer region of BCL11A gene in in-vitro into two products with the size of approximately $240 \mathrm{bp}$. The gene sequencing showed that the rCas9/sgRNA complex cut exactly the GATAA enhancer region of BCL11A gene at a position of 3 nucleotides away from the PAM region according to theoretical calculations. Conclusion: Recombinant Cas9 protein had a similar activity as natural Cas9 protein and rCas9/sgRNA complex needs to be further studied for application in BCL11A gene editing to treat sickle cell disease in clinical practice.

Keywords: CRISPR/Cas9 system; sickle cell disease; gene editing

\section{I. ĐĂT VẤN ĐỀ}

Công nghê chỉnh sửa gen sử dụng CRISPR/Cas9 là một trong những tiến bô vượt bậc trong lĩnh vực sinh học phân tử,đã và đang được ứng dụng rộng rãi trong các lĩnh vực từ sinh học, nông nghiệp, y học. [1],[3]. Trong lĩnh vực y học, các nhà khoa học đã ứng dụng công nghệ CRISPR để chữa các bệnh di truyên [5],[6]. Hệ thống CRISPR/Cas9 bao gồm 2 thành phân: enzyme Cas9 nuclease và RNA dẫn đường (sgRNA). Nhờ đoạn trình tự bổ sung của RNA dẫn đường với trình tự đích mà phức hợp này có thể tìm thấy vị trí cân chỉnh sửa trên hệ gen.Để có thể hoạt động, hệ thống CRISPR còn yêu câu 